\title{
Misbranding of Ayurvedic pharmaceutical preparations A market survey report
}

\author{
Research Article
}

\section{Piyush Chaudhary $^{1^{*}}$, Balian SK}

1. Research Scholar, Deptt of Rasa Shastra, 2. Reader, Rajiv Gandhi Govt. PG Ayurveda College, Paprola, Kangra, HP

\begin{abstract}
Background: The annual turnover of the Indian herbal medicinal industry is about Rs. 7,500 crore as against the pharmaceutical industry's turnover of Rs. 14,500 crores with a growth rate of more than $15 \%$. Certainly some regulations are required to keep a check on this massive industry. Drugs and Cosmetics Act, 1940 (D\& C Act) lays down the regulatory and recommendatory standards for Ayurvedic drugs. Objective: The present survey study was undertaken to assess the compliance of the D \& C Act by the Ayurveda drugs manufacturing units. The guidelines laid down by this act formed the basis of the study. Materials \& Methods: A total of 100 drug labels from 13 different major pharmaceutical houses were collected from the market and analysed on the basis of guidelines for labelling laid down under D\&C Act, 1940. Results: It was found that none of the labels satisfied all the guidelines pertaining to labelling standards of the Ayurvedic drugs. It was observed that $92 \%$ drug labels did not mention the API standards of the drugs used while $99 \%$ drug labels did not mention the part of the plant used. Conclusions: It was inferred that potentially large number of the Ayurvedic drugs being marketed in India are misbranded.
\end{abstract}

Key Words: Drugs and Cosmetics Act, Labelling, Misbranded drugs.

\section{Introduction}

In the age of modern technology, scientific advancements, consumer awareness and the advent of evidence based medicine, attention has been given towards the quality control and marketing of the Ayurveda drugs. In India, there are about 14 well-recognized and 86 medium scale manufactures of herbal drugs. Other than this about 8,000 licensed small manufactures in India are on record(1). The annual turnover of the Indian herbal

*Corresponding Author:

\section{Piyush Chaudhary}

Research Scholar, Deptt of Rasa Shastra, Rajiv Gandhi Govt. PG Ayurveda College, Paprola, Kangra, HP, Email: piyush0911@gmail.com, Phone no: 9418162457, 9736333869 medicinal industry is about Rs. 7,500 crore as against the pharmaceutical industry's turnover of Rs. 14,500 crores with a growth rate of more than 15 percent. As per study commissioned by the Associated Chamber of Commerce and Industry (ASSOCHAM), the Indian herbal industry is projected to double to Rs. 15,000 crore by 2015 , from the current 7,500 core business. The apex chamber estimates global herbal industry to grow to Rs 70,000 crore by 2015 , more than double from the current level of Rs 30,000 crore.(2)

Certainly some laws are required to govern this sector so as to keep a tab on drugs being manufactured and consumed by people across the nation. Manufacture and quality control of Ayurvedic, Siddha and Unani (ASU) medicines come under the purview of Drugs \& Cosmetics Act, 
1940 (D\&C Act), which also incorporates the regulatory and recommendatory standards for these drugs. Drugs \& Cosmetics Act, 1940 has a separate chapter IV- A(3) which states all the guidelines to be followed for manufacturing, packaging \& labelling of ASU drugs. The latest amendments in this chapter were done on 22 March 2013 vide a Gazette notification by the Central Government(4). This notification laid certain new guidelines for labelling of the ASU drugs.

\section{Aim \& Objectives}

The present study was undertaken to evaluate the compliance of Drugs \& Cosmetics Act, 1940 and rules made there under and amended from time to time pertaining to labelling standards of Ayurveda drugs.

\section{Material \& Methods}

A market survey was done and 100 labels of various Ayurvedic medicines were collected from chemists in the state of Himachal Pradesh. It was a random selection and comprised of classical medicine as well as patent/ proprietary medicine. In all, the drugs from 13 different pharmaceutical houses including the major pharmacies of India, having manufacturing units in different states, were collected and studied.

Misbranded Drugs(5):- As per Rule 33-E Chapter IV-A, an Ayurvedic, Siddha or Unani drug shall be deemed to be misbranded,-

a) If it is so coloured, coated, powdered or polished that damage is concealed, or if it is made to appear of better or greater therapeutic value than it really is; or

b) If it is not labelled in the prescribed manner; or

c) If its label or container or anything accompanying the drug bears any statement, design or device which makes any false claim for the drug or which is false or misleading in any particular.

Also, Rule 33-EEC prohibits the manufacture for sale or for distribution any misbranded, adulterated or spurious ASU drugs.

Rule 33-I states the penalty for manufacture, sale etc. of ASU drugs including imprisonment up to one year and fine not less than twenty thousand rupees or three times the value of the drugs confiscated, whichever is more

Rule 161(5) of the D \& C Act, 1940 states the mandatory guidelines for labelling, packing and limit of alcohol which are as under

(1) There shall be considerably displayed on the label of the container or package of an Ayurvedic (including Siddha) or Unani drug, the true list of all the ingredients with their official names( for herbal ingredients) along with parts used \& form of ingredients, in which, it is used in the manufacture of the preparation together with quantity of each of the ingredients incorporated therein and a reference to the method of preparation thereof as detailed in the standard text and Adikarana, as are prescribed in the authoritative books specified in the First Schedule to the Act \& in respect of Patent or Proprietary ASU drugs, the true list of all ingredients with their official \& botanical names (for herbal ingredients) along with part used \& form of ingredient, in which it is used in the formulation, with its quantity.

Provided that if the list of ingredients contained in the medicine is large and cannot be accommodated on the label, the same may be printed separately and enclosed with packing and reference be made to this effect on the label.

(2) The container of a medicine for internal use made up ready for the treatment of human ailments shall, if it is made up from a substance specified in Schedule E (1), be labelled conspicuously with the words 'Caution: To be taken 
under medical supervision' both in English and Hindi language.

(3) Subject to the other provisions of these rules, the following particulars shall be either printed or written in indelible ink and shall appear in a conspicuous manner on the label of the innermost container of any Ayurvedic (including Siddha) or Unani drug and on any other covering in which the container is packed namely--

(i) The name of the drug. For ASU drugs, the name shall be the same as mentioned in the authoritative books included in the First Schedule of the Act.

(ii) A correct statement of the net content in terms of weight, measure or number as the case may be. The weight and volume shall be expressed in metric system.

(iii) The name and address of the manufacturer.

(iv) The number of the licence under which the drug is manufactured.

(v) A distinctive batch number, that is to say, the number by reference to which details of manufacture of the particular batch from which the substance in the container is taken are recorded and are available for inspection.

(vi) The date of manufacture. For this purpose the date of manufacture shall be the date of completion of the final products, or the date of bottling or packing for issue.

(vii) The words "Ayurvedic medicine" or "Siddha medicine" or "Unani medicine" as the case may be.

(viii) The words "FOR EXTERNAL USE ONLY" if the medicine is for external application.

(ix) Every drug intended for distribution to the medical profession, as a free sample shall, while complying with the labelling provisions under clauses (i) to (viii), further bear on the label of the container the words "Physicians sample. Not to be sold" which shall be over-printed.

(x) (a) Preparation (Asavas) with high content of alcohol as base

\begin{tabular}{|l|c|}
\hline Name of the drug & $\begin{array}{l}\text { Maximum size of } \\
\text { packing }\end{array}$ \\
\hline (i) Karpur Asava & $15 \mathrm{ml}$ \\
\hline (ii) Ahiphensava & $15 \mathrm{ml}$ \\
\hline (iii) Mrgamadasava & $15 \mathrm{ml}$ \\
\hline
\end{tabular}

(x) (b) Preparations containing selfgenerated alcohol

\begin{tabular}{|l|l|l|}
\hline Name of the drug & $\begin{array}{l}\text { Maximum } \\
\text { content of } \\
\text { alcohol }\end{array}$ & $\begin{array}{l}\text { Maximum } \\
\text { size of } \\
\text { packing } \\
\text { thyl } \\
\text { alcohol } \\
\text { v/v) }\end{array}$ \\
$\begin{array}{l}16 \quad \text { per } \\
\text { cent }\end{array}$ & $30 \mathrm{ml}$. \\
\hline $\begin{array}{l}\text { (i) Mritsanjivani } \\
\text { Sura }\end{array}$ & $\begin{array}{l}16 \text { per } \\
\text { cent }\end{array}$ & $120 \mathrm{ml}$ \\
\hline $\begin{array}{l}\text { (ii) Mahadrakshasava } \\
\text { Mi) }\end{array}$
\end{tabular}

Rule 161-B mentions the expiry date of the various drug dosage forms of ASU drugs, which has to be inconspicuously written on the label.

SCHEDULE J (Rule 106) (5) mentions the diseases and ailments (by whatever name described) which a drug may not purport to prevent or cure or make claims to prevent or cure.

The present study was done by taking into consideration, the provisions of D\&C Act pertaining to the labelling \& packaging of ASU drugs. The features inscribed over the labels that have been incorporated in the study are as following

1. Name of Medicine

2. Classical Ayurvedic Medicine or Patent/ Proprietary Medicine, as the case may be

3. API standardization of ingredients

4. Formulation Composition

5. Adhar Granth/ Reference 
6. Official Name of ingredients

7. Botanical Name of ingredients

8. Part Used (of ingredients)

9. Quantity/percentage of ingredients

10. Form in which ingredient is used

11. Precautionary warning (Hindi \& English), if any Schedule E drug is used as ingredient

12. Whether Drugs have been used in Shuddha form, for which shodhan is required

13. Manufacturing Address

14. Manufacturing Licence Number

15. Batch Number

16. Date of Manufacture \& date of Expiry

17. Whether intended for External use

18. Dose to be taken

19. Indication

20. Whether complies to Schedule J, in case of indications

21. Permitted excipients \& colors used

\section{Observations \& Results}

$\begin{array}{crrr}\text { A total of } & 100 & \text { different } \\ \text { formulations } & \text { from } & 13 & \text { major }\end{array}$ pharmaceutical companies were randomly selected and studied. Of these 75 formulations were proprietary medicines, while 25 were classical Ayurvedic formulations. There were 18 drugs containing poisonous drug as stated under Schedule E-1. There was one eye drops preparation included in the study. There were 3 classical Ayurvedic preparations containing self-generated alcohol.( asavaarishta). (Table -1)

Table -1, Total distribution of type of drugs included in the study

\begin{tabular}{|l|l|l|}
\hline Feature & $\begin{array}{l}\text { Total } \\
\text { number }\end{array}$ & Percentage \\
\hline $\begin{array}{l}\text { Classical Ay. } \\
\text { Formulations }\end{array}$ & 25 & $25 \%$ \\
\hline $\begin{array}{l}\text { Proprietary } \\
\text { Ay. } \\
\text { Formulation }\end{array}$ & 75 & $75 \%$ \\
\hline $\begin{array}{l}\text { Eye drops } \\
\text { preparation }\end{array}$ & 1 & $1 \%$ \\
\hline
\end{tabular}

\begin{tabular}{|l|l|l|}
\hline $\begin{array}{l}\text { Alcoholic } \\
\text { preparation } \\
\text { (asava-arishta) }\end{array}$ & 3 & $3 \%$ \\
\hline
\end{tabular}

It was observed that all the formulations had the term "Ayurvedic medicine", the manufacturing address, license number, batch number, date of manufacture and dosage clearly stated on the labels (Table-2). Of the total drug labels studied, 19 drugs were intended for external use only and all of these drugs had clear indication regarding their external use.

Table-2, Compliance of various features pertaining to Labelling according to D\&C Act, 1940

\begin{tabular}{|l|l|l|}
\hline Feature & $\begin{array}{l}\text { Total } \\
\text { number of } \\
\text { formulation } \\
\text { s }\end{array}$ & $\begin{array}{l}\text { Percentag } \\
\text { e }\end{array}$ \\
\hline $\begin{array}{l}\text { The term } \\
\text { "Ayurvedic } \\
\text { Medicine" }\end{array}$ & 100 & $100 \%$ \\
\hline $\begin{array}{l}\text { Manufacturin } \\
\text { g address }\end{array}$ & 100 & $100 \%$ \\
\hline $\begin{array}{l}\text { Licence } \\
\text { number }\end{array}$ & 100 & $100 \%$ \\
\hline Batch number & 100 & $100 \%$ \\
\hline $\begin{array}{l}\text { Date of } \\
\text { manufacture }\end{array}$ & 100 & $100 \%$ \\
\hline $\begin{array}{l}\text { Indication for } \\
\text { External Use } \\
\text { Only }\end{array}$ & 19 & $100 \%$ \\
\hline Dose & 100 & \\
\hline
\end{tabular}

The formulation composition was written completely on $95 \%$ drug labels, while it was incomplete in $5 \%$ cases. It was an important observation as these 5\% cases were found to be of a single pharmacy and included only classical medicines. Only the main ingredients were mentioned. It was found that very few pharmacies had indicated on the label, whether the ingredients used were of API standard or not as depicted in Table No.- 3. Only $8 \%$ formulations from a renowned 
Pharmaceutical house had stated that the ingredients used were of API standards. The Ayurvedic Pharmacopoeia of India clearly mentions the official names ${ }^{(6)}$ of the medicinal plants which are used as raw material for drug manufacturing. The D\&C Act, makes it mandatory to mention the official name as well as Botanical name of the herbal ingredients used. Most of the compositions had either vernacular names or common names written on the labels. Official name as per API were mentioned on $58 \%$ labels while $42 \%$ labels did not have official name written on them. Botanical names were also not given in most of the labels which has been mandated by the Act. Only 67\% formulations had the botanical names of the ingredients written over the labels while 33\% did not have botanical names written over the labels. Only $1 \%$ of the labels had specified the part of the plant used in composition. The quantity of each ingredient used was written completely on $95 \%$ drug labels, while it was not written in $5 \%$ cases. (Table-3).

Table- 3, Distribution of Non Compliance of various features of Labelling

\begin{tabular}{|l|l|l|}
\hline Feature & Compliance & $\begin{array}{l}\text { Non } \\
\text { Compliance }\end{array}$ \\
\hline $\begin{array}{l}\text { Formulation } \\
\text { Composition }\end{array}$ & $95 \%$ & $5 \%$ \\
\hline $\begin{array}{l}\text { API } \\
\text { Standard of } \\
\text { Ingredients }\end{array}$ & $\mathbf{8 \%}$ & $\mathbf{9 2 \%}$ \\
\hline $\begin{array}{l}\text { Official } \\
\text { Name }\end{array}$ & $\mathbf{5 8 \%}$ & $\mathbf{4 2 \%}$ \\
\hline $\begin{array}{l}\text { Botanical } \\
\text { Name }\end{array}$ & $67 \%$ & $33 \%$ \\
\hline Part Used & $\mathbf{1 \%}$ & $\mathbf{9 9 \%}$ \\
\hline $\begin{array}{l}\text { Quantity of } \\
\text { ingredient } \\
\text { used }\end{array}$ & $95 \%$ & $5 \%$ \\
\hline Expiry date & $95 \%$ & $5 \%$ \\
\hline $\begin{array}{l}\text { Indication of } \\
\text { the drug }\end{array}$ & $83 \%$ & $17 \%$ \\
\hline $\begin{array}{l}\text { Schedule J } \\
\text { provisions }\end{array}$ & $94 \%$ & $6 \%$ \\
\hline
\end{tabular}

The D\&C, Act under rule 161-B mentions the expiry date of almost all drug dosage forms. However in our study $5 \%$ drugs did not have any mention of the expiry date. Even if a drug has indefinite expiry period, a mention of such should be made on the label. The indication for which the drug is intended to be used should be depicted on the label. However, it should not contradict the provisions as laid down under Schedule (Sch) J, which bars the claim of the drug to cure or heal certain disease as mentioned under it. Keeping this rule in view, $6 \%$ drugs were found to be violating the provision of Sch. $\mathrm{J}$ (Table-3). The indications mentioned on these drugs included obesity, liver disorders, uterine disorders, diabetes.

Of the total drug labels studied, 18 had contents falling under Schedule E list. Out of these 18 drugs the caution warning was mentioned on 15 labels in both languages. (Table-4)

Table- 4, Schedule E specifications on labels

\begin{tabular}{|l|l|}
\begin{tabular}{|l|} 
No. of drugs containing \\
Sch E drugs
\end{tabular} & Percentage \\
\hline 18 & $18 \%$ \\
\hline $\begin{array}{l}\text { Caution warning mentioned on labels in } \\
\text { both languages. }\end{array}$ \\
\hline 15 & $83.33 \%$ \\
\hline
\end{tabular}

It was observed that 32 drugs had ingredients which were required to be used after Shodhan. Hence it should be mentioned on the label, whether Shodhit drug has been used or not in composition. Of these $40.62 \%$ (13 Drugs) drugs did not mention, if the "Shodhit" ingredient was used, while $59.38 \%$ (18 drugs) mentioned on the label (table-5), the ingredients were used after Shodhan.

All the drug labels studied had indicated the permitted excipients used, preservatives added, if any and the colour permitted.( Table -6)

Table- 5, Distribution of drugs in which one or more ingredient is required to be used after Shodhan 


\begin{tabular}{|l|l|l|}
\hline $\begin{array}{l}\text { Total } \\
\text { number of } \\
\text { Labels } \\
\text { containing } \\
\text { the }\end{array}$ & $\begin{array}{l}\text { Whether } \\
\text { ingredient } \\
\text { is used } \\
\text { ingredients } \\
\text { Shodhan as } \\
\text { required to } \\
\text { be used } \\
\text { after } \\
\text { Shodhan }\end{array}$ & $\begin{array}{l}\text { Not used } \\
\text { after } \\
\text { Shodhan as } \\
\text { onentioned label } \\
\text { on loged } \\
\text { (\%)age) }\end{array}$ \\
\hline 32 & $\begin{array}{l}\text { (\%) } \\
\end{array}$ & \\
\hline
\end{tabular}

Table-6, Compliance of various features pertaining to Labelling according to $\mathrm{D \& C}$ Act, 1940

\begin{tabular}{|l|l|l|}
\hline Feature & $\begin{array}{l}\text { Complianc } \\
\text { e }\end{array}$ & $\begin{array}{l}\text { Non } \\
\text { Complianc } \\
\text { e }\end{array}$ \\
\hline $\begin{array}{l}\text { Permitted } \\
\text { Excipients }\end{array}$ & $100 \%$ & $0 \%$ \\
\hline $\begin{array}{l}\text { Preservative } \\
\text { s }\end{array}$ & $100 \%$ & $0 \%$ \\
\hline $\begin{array}{l}\text { Permitted } \\
\text { Colours }\end{array}$ & $100 \%$ & $0 \%$ \\
\hline
\end{tabular}

Of the total drugs studied, only one drug came under the purview of Schedule FF, as it was an eye drop. (Table-1) It complied with all the provisions of the schedule.

\section{Discussion}

The present study was undertaken to evaluate the impact of Drugs \& Cosmetics Act and its implementation pertaining to the labelling standards of Ayurvedic drugs. The Government of India closely monitors the standards of all the drugs being manufactured \& marketed in India and takes various steps at improving the quality and standards of these medicines ${ }^{(7)}$. Various notifications and amendments in D\&C Act, from time to time are an ample proof of close vigil of the Central Government on the pharmaceutical industry.

Almost all the major players of the Ayurvedic pharmaceutical industry were included in this study and it was observed that potentially higher percentage of drug labels do not comply to the provisions of Rule 33-E (b) of D\&C Act, thus rendering them as Misbranded Drugs. If these big pharmacies do not follow the provisions of the Act, then the quality of drugs manufactured by other 8000 small pharmacies can very well be imagined.

Though the basic information like the term "Ayurvedic Medicine", Manufacturing address, Licence number, Batch number, Date of manufacture, Indication for External Use Only, Dose were included on all the labels, yet the main observation was that $92 \%$ drug labels did not have the standard of ingredients as per API written over them. Moreover 99\% labels did not have the part of the ingredient used mentioned over it. Some drugs did not even mention the whole formulation composition either on label or as an insert leaflet inside the packing. Some serious flaws were observed pertaining to official names and botanical names also.

Improper labelling gives incomplete or misleading information (e.g. which part of the plant is used as ingredient) about the drug, as a result of which the quality control methods of Identity, Purity and Strength as per API norms cannot be established. Transparency regarding the drug and its constituents cannot be maintained. It can be inferred from the above observations that the Ayurveda drugs manufacturing units are not serious about the provisions laid down in the Act. This lack lustre attitude of the pharmacies has led to large scale marketing of Misbranded drugs.

This situation can be improved by exploiting the services of the experts of Ayurveda who are well apprised of the laws and regulations pertaining to manufacturing of drugs. Regular inspections should be done and drug samples should be checked on every parameter of the Act. Emphasis should be given on quality control at every step of drug manufacturing and its marketing. 
Moreover, the drug inspectors should be re-oriented and trained, so that they are able to check the non-compliance of the Act and its provisions. Also, legal action may be taken by the State Ayurvedic Drug Controlling Authority against such Ayurvedic Pharmacies manufacturing Misbranded drugs as per the provisions of D\&C Act, 1940 so as to assure transparent and good quality products.

This survey should act as an eye opener to the authorities as well as stake holders of the Ayurvedic pharmaceutical industry so that complete and correct information is provided on the labels and prevent the drugs from being termed as Misbranded.

\section{Conclusion}

The study highlights the seriousness of problem of Misbranding (not labelled as per law) of Ayurvedic drugs being marketed in India, as their labels do not give correct and complete information as per the Drugs \& cosmetics Act, 1940 and amendments made into it from time to time. A study sample of hundred labels of classical and proprietary medicines of reputed houses has clearly brought out the violation of statutory provisions of D\&C Act by major stake holders. Smaller regional manufacturers may be violating the act more seriously at the loss to the consumer. It is high time that regulatory authorities recognise the problem of misbranding of ASU drugs and take steps to enforce the provisions of D\&C Act more seriously.

\section{Acknowledgement:}

The authors are highly thankful to Prof. Y.K. Sharma, Dean \& Principal, Rajiv Gandhi Govt. PG Ayurvedic College, Paprola for his support towards the study and valuable suggestions in preparing the manuscript. We are also thankful for help rendered by all the medical stores, who provided with the various drugs along with their labels for the survey and the scholars who played a very important role in summarising the study.

\section{References}

1. Kirti Joshi, Indian Herbal Sector, 2008 (accessed on 2013 July 28) Available from

http://www.nistads.res.in/indiasnt2008/ t4industry/t4ind19.htm.

2. Niir project consultancy services, 2013, New Delhi (accessed on 2013 July 29) Available from http://www.niir.org/profiles/profiles/he rbs-herbal-based-products-ayurvedicmedicines-cosmetics-herbs-medicinalplants-cultivation-processing-herbalextract-natural-plant-extractsayurvedic-pharma-ayurvedic-productsherbal-medicine-herbal-cosmeticsayurvedicformulations/z, d, $0, \mathrm{a} /$ index.html.

3. Vijay Malik, Laws relating to Drugs and Cosmetics, 22 $2^{\text {nd }}$ ed. Lucknow, Eastern Book Company, 2012. p. 46

4. Notification issued by Government of India (accessed on 2013 July 29) available from http://indianmedicine.nic.in/writereadd ata/linkimages/5577992979K\%2011020\%205\%202011.pdf

5. Vijay Malik, Laws relating to Drugs and Cosmetics, 22 ${ }^{\text {nd }}$ ed. Lucknow, Eastern Book Company, 2012. p.48, 223-4, 403

6. The Ayurvedic Pharmacopoeia of India, Part 1, Vol1, Department of Ayush Government of India, New Delhi. p.viii

7. Department of Ayush, Govt. of India (accessed on 2013 July 29) Available from http://indianmedicine.nic.in/ 